\title{
Diálogos epistolares: Eça de Queiroz e as Cenas portuguesas
}

\author{
Epistolary dialogues: Eça de Queiroz and the Portuguese scenes \\ Claudia Barbieri \\ Universidade Estadual Paulista - Araraquara - São Paulo - Brasil
}

$\diamond$

\begin{abstract}
Resumo: Desde a morte de Eça de Queiroz, no ano de 1900, uma série de edições procuraram reunir os diferentes acervos epistolares do escritor: cartas de seu trabalho no Consulado, cartas íntimas trocadas entre sua esposa, filhos e amigos, cartas profissionais para os seus editores. Nesses discursos privados eram revelados aspectos de sua personalidade, projetos literários, revisões e críticas de seus trabalhos publicados ou em processo de criação. Em sua epistolografia descobrimos, por exemplo, o extenso projeto das Cenas portuguesas - idealizado na segunda metade da década de 1870. Nas linhas dessas missivas trocadas entre Eça, seu editor Ernesto Chardron e seus amigos, encontramos o discurso vivo, imaginativo e sagaz característico da prosa queiroziana. É do processo de concepção e desenvolvimento das Cenas portuguesas que trata este artigo.
\end{abstract}

Palavras-chave: Eça de Queiroz; Epistolografia queiroziana; Cenas portuguesas

\begin{abstract}
Since the Eça de Queiroz's death, in the year of 1900, a serie of editions sought to bring together different epistolary collections from the writer: letters of his work in the Consulate, intimate letters exchanged between his wife, children and friends, professional letters to his editors. In these private discourses were revealed aspects of his personality, literary projects, reviews and critiques of his work published or in the creation process. In his epistolography we found, for example, the extensive project of the Portuguese Scenes - idealized in the second half of the 1870s. In the lines of these letters exchanged between Eça, his editor Ernesto Chardron and his friends, we find the speech live, imaginative and clever characteristic of queirozian prose. It is about of the conception process and development of the Portuguese Scenes that's what this article.
\end{abstract}

Keywords: Eça de Queiroz; Queirozian epistolography; Portuguese scenes

Eça epistológrafo, mesmo como autor de cartas intimas, não abdica nunca do brilhante estatuto de criador ficcional.

(MATOS, 1996, p. 12)

Oito anos após a morte do escritor francês VictorMarie Hugo (1802-1885), sairia publicado no dia 14 de julho de 1893, na primeira página da Gazeta de Notícias do Rio de Janeiro, cinco notícias escolhidas pelo escritor português Eça de Queiroz (1845-1900), então correspondente do jornal carioca, na capital francesa onde residia. Tal assídua contribuição - que levava o amplo título Ecos de Paris - seria postumamente reunida e organizada pelo amigo Luiz de Magalhães (1859-1935), na edição de mesmo nome e publicada no ano de 1905. Dentre as cinco notícias, que ocupavam da quarta à sexta coluna do periódico, Eça mencionava que havia sido lançado, no início daquele mês, mais um volume de versos do escritor francês, com poemas não publicados em vida por ele. Eça questionava se tal atitude não poderia prejudicar a glória literária erigida por Hugo, uma vez que tais publicações póstumas traziam a lume um material descartado, "atirado para o canto" e esquecido completamente pelo poeta. Ao responder a este questionamento, Eça deixou-nos essas oportunas palavras: ${ }^{1}$

\footnotetext{
1 Todas as transcrições de documentos e cartas manterão a grafia e a pontuação originais das publicações.
} 
Ora quantos mais documentos se reunem sobre um homem de genio como Hugo, mais completo se torna o trabalho critico sobre a sua individualidade e sobre a sua obra. Para alargar e completar o conhecimento dos grandes homens, publicam-se-lhe as cartas, todos os papeis íntimos - até as contas do alfaiate. Assim se tem feito para Lamartine, para Balzac, etc. (EÇA DE QUEIROZ, 1893, p. 1)

Como um homem de gênio que foi, Eça de Queiroz viria a ter o mesmo destino. Após a sua morte em 16 de agosto de 1900, uma série de publicações, que apareceram ao longo dos anos posteriores, incluíram romances e contos inéditos ou inacabados, cartas íntimas e públicas aos mais diversos destinatários, contas, postais, bilhetes, fotografias e desenhos que em conjunto, revelavam não apenas os mais interessantes e curiosos aspectos de sua vida, mas, também, os seus planos de escritor e o seu rico processo de criação literária.

Assim, este artigo tem o objetivo de apresentar a correspondência trocada entre Eça e o seu editor, Ernesto Chardron (1840-1885), e entre o escritor e os seus amigos ao longo da segunda metade da década de 1870 , período esse considerado pelos estudiosos da obra queiroziana como um dos mais fecundos da sua carreira literária. Neste acervo epistolar ficou o registro, talvez, do mais ambicioso e complexo projeto já concebido pelo autor de $O$ crime do padre Amaro, mas nunca realizado na plenitude idealizada e descrita por ele nessas missivas: as Cenas portuguesas.

Deste modo, para melhor compreensão desse recorte temporal, mostra-se necessário resgatar a história da carreira literária de Eça desde 1875 e mostrar qual o percurso traçado por ele nos anos que se seguiram.

Entre 15 de fevereiro e 15 de maio de 1875, é publicado O crime do padre Amaro na Revista Ocidental, quinzenário fundado por Oliveira Martins (1845-1894) e dirigido pelos velhos amigos de Eça, Antero de Quental (1842-1891) e Jaime Batalha Reis (1847-1935). Essa primeira impressão foi motivo de grandes discussões e desentendimentos. Transferido para Newcastle, na Inglaterra, por motivos referentes ao seu trabalho no Consulado, Eça, no primeiro semestre de 1875, manda os fascículos iniciais, esperando corrigi-los nas provas, o que não aconteceu. Levados, talvez, pela falta de tempo, Antero e Batalha Reis operaram no texto mutilações e correções, imprimindo-o sem consulta ao autor. Eça, indignado, chegou a solicitar a suspensão da publicação, sem obter êxito. Nas semanas que se seguiram, o escritor pediu ao amigo Ramalho Ortigão (1836-1915) que acompanhasse as impressões por ele, e a primeira versão do romance segue a publicação até o final.

Insatisfeito com a impressão na Revista Ocidental, Eça tratou logo de preparar a edição do romance em volume. Em uma rápida estada em Portugal, procurou por Ernesto Chardron no Porto, proprietário de uma importante editora, e perguntou sobre o possível interesse do editor na publicação do Padre Amaro. Por motivos de saúde, Chardron não pôde assumir o compromisso e, pouco tempo depois, Eça teve que retornar para Newcastle. Nesse momento, o pai do escritor, Dr. José Maria de Almeida Teixeira de Queiroz, resolveu financiar a publicação do livro, o qual foi posto à venda em 1876, com uma tiragem de apenas 800 exemplares:

La impresión de la edición fue costeada por el padre de Eça, José Maria de Almeida Teixeira de Queiroz, que se hizo responsable ante el librero editor, Ernesto Chardron, - que la compró para revenderla. "Procure promover a saída do livro, e se meu filho lhe escrever para saber como vai a venda, não o desanime, pois ele tem 'geiteira' para as letras; de resto, eu tomo a responsabilidade por qualquer prejuízo que o seu insucesso ocasione". Con la venta en depósito de $\mathrm{O}$ crime do padre Amaro comenzaron las relaciones de Eça con el librero Chardron - que pasaría a ser su editor. (GUERRA DA CAL, 1975, tomo $1^{\circ}$, p. 22)

Em meados de 1876, portanto, têm início os longos anos de diálogo epistolar entre o escritor e o editor: missivas valiosas, nas quais Eça apresentava seus projetos, intenções, ideias de livros e orientações sobre as publicações, como formato da impressão, tipo de letra, papel e estilo de capa. No segundo semestre deste ano, Eça engendra a escritura de $O$ primo Basílio, que possui as datas "Setembro de 1876 - Setembro de 1877 " no manuscrito. No início do ano seguinte, em 21 de fevereiro de 1877, há uma pequena referência ao romance em uma carta para Chardron:

\begin{abstract}
Cuando le comunicó a Chardron que estaba dando los ultimos retoques a una nueva novela de costumbres contemporáneos, tuvo cuidado de aclarar "não da província desta vez - mas de Lisboa. É um trabalho realista, talvez um pouco violento e cru". (GUERRA DA CAL, 1975, tomo $1^{\circ}, \mathrm{p}, 37$ )
\end{abstract}

Entretanto seria em uma correspondência datada de 5 de outubro de 1877 que o escritor apresentaria a sua primeira grande proposta para a editora:

Eu tenho uma idéia, que penso daria excelente resultado. É uma coleção de pequenos romances, não excedendo de 180 a 200 páginas, que fosse a pintura da vida contemporânea em Portugal: Lisboa, Porto, províncias, políticos, negociantes, fidalgos, jogadores, advogados, médicos, todas as classes, todos os costumes entrariam nesta galeria. A coisa poderia chamar-se Cenas da Vida Real, ou qualquer 
outro título genérico mais pitoresco. Cada novela teria depois o seu título próprio. Como compreende, estas novelas devem ser curtas, condensadas, todas de efeito, e não devem exceder 12 volumes. Poderiam ser publicadas de dois em dois meses, ou com menor espaço. Não se começaria a publicação da primeira, sem haver o manuscrito de três. Os personagens de uma apareceriam nas outras, de sorte que a colecção formaria um todo. Seriam trabalhadas de modo, e com tanta pimenta, que fariam sensação, mesmo em Portugal. Eu já tenho o assunto de três novelas, e uma quase completa. Numa delas pintarei o jogo e os jogadores, noutra a prostituição, a última é um drama de incesto doméstico. Já vê que não vou com meias medidas, e que ataco o touro pelos cornos, como dizem os franceses. $\mathrm{O}$ encanto destas novelas - que são mais difíceis de fazer do que um romance - é que não há digressões, nem declamação, nem filosofia: tudo é interesse e drama, e rapidamente contado: lê-se numa noite e fica-se com a impressão para uma semana. Eis a ideia em geral. Preciso saber rapidamente se lhe convém - e as vantagens que me oferece - porque estou agora desocupado, e como de Lisboa me tentam muito para um drama, preciso saber o que hei-de fazer. A mim esta ideia das novelas encanta-me. Há uma quantidade de assuntos escabrosos que se não podem tratar num longo romance e que se dão perfeitamente bem na novela. No caso que V. Ex. ${ }^{a}$ queira, vamos à obra. (EÇA DE QUEIROZ apud MATOS, 2000, p. 86)

Esta "coleção de pequenos romances", que recebeu no início o título Cenas da Vida Real, era um projeto de Eça idealizado segundo os moldes da Comédia Humana de Balzac, com o objetivo de retratar os fatos mais característicos da sociedade portuguesa - seus costumes, tradições, contextos sociais, etc. Na mesma carta mencionada aparece a primeira referência ao manuscrito que viria a ser conhecido como A tragédia da Rua das Flores:

Em todo o caso uma das novelas está quase pronta - é só copiá-la: chama-se $O$ desastre da Travessa do Caldas ou, talvez, não sei ainda, $O$ caso atroz da Genoveva. Trata-se dum incesto involuntário. Dará, creio, 200 páginas, ou mais. Alguns amigos a quem comuniquei a ideia dela e parte da execução, ficaram impressionados, ainda que um pouco escandalizados. - Não quer dizer que seja imoral ou indecente. É cruel. Que lhe parece o livrinho como d'étrennes para o $1^{\circ}$ de janeiro? (EÇA DE QUEIROZ, 1979, v. III, p. 9-10)

O projeto das Cenas, ao que parece, interessou sobremaneira o editor e continuou se desenvolvendo, agora sob o título Crônicas da Vida Sentimental. Encontramos a próxima referência em epístola de 3 de novembro de 1877 , onde além de esclarecer melhor o assunto, apresenta proposta para a comercialização dos volumes:
Tenho pensado no nosso negócio das Crónicas e eis o que julgo poder propor-lhe de melhor: As Crónicas da Vida Sentimental (título provisório) constam de doze volumes. Cada um destes volumes tem 200 páginas. A sua publicação não pode nem deve ter a regularidade fixa e invariável dum jornal e duma revista. Mas os intervalos de publicação não devem exceder a seis semanas. Cada um dos romances tem a sua acção própria e desenlace próprio; mas sendo estudos dos factos mais característicos da nossa sociedade, formam, no seu todo, um quadro geral da vida contemporânea. A obra é uma espécie de galeria de Portugal no século XIX. Para produzir, porém, um alto grau de interesse - é necessário dar-lhes diversidade. Assim, alguns pintarão costumes gerais da nossa sociedade: $O$ prédio $n^{\circ}$ 16, será o jogo; A linda Augusta, a prostituição; O bacharel Sarmento, a educação e as escolas, etc. Outros, serão o estudo de alguma paixão ou drama excepcional: assim a Genoveva é o incesto; Sóror Margarida, a monomania religiosa; teremos ainda $O$ Milagre do Vale de Reriz, para mostrar o fanatismo das aldeias; $O$ bom Salomão dar-nos-á a agiotagem, etc. Por cada um destes romances proponho o preço de $£ 35$. E proponho mais - que depois de publicado o $3^{\circ}$ volume, se tivessem um sucesso considerável, este contrato fosse sujeito a revisão, dum modo e em bases mais equitativas para mim.

Classifico um sucesso considerável a venda rápida de 1600 a 2000 exemplares. Em definitivo - proponho o preço de 35 libras para os três primeiros volumes somente. Esta proposta provém dos singulares assuntos e planos que tenho descoberto, e que são próprios para excitar o público menos interessado e mais adormecido, por exemplo, A linda Augusta, $O$ bom Salomão, etc. Isto, naturalmente, é a proposta para V. Ex. ${ }^{a}$ meditar, e discutirmos. O primeiro volume está muito adiantado. Não tenho título definitivo; hesito: talvez $O$ desastre da Rua das Flores, talvez Os amores dum lindo moço. Em todo caso é o incesto. Julgo-o infinitamente superior (sem comparação possível) ao Primo Basílio. E confesso que estou ansioso por o ver publicado. O Primo Basílio é mais para o público literário mas este é uma verdadeira bomba literária e moral. Dá 250 páginas; seria todavia possível fazê-lo caber nas 200. Espero a sua resposta breve. (EÇA DE QUEIROZ apud MATOS, 2000, p. 86-87)

Em uma única missiva Eça utiliza-se de três títulos diferentes para referenciar o manuscrito de $A$ tragédia $d a$ Ruas das Flores que, segundo seu autor, encontrava-se "muito adiantado". À essa época o escritor, para além de trabalhar na redação do manuscrito, terminava a revisão das provas de $O$ primo Basílio $^{2}$. Do mesmo dia 3 de novembro de 1877 data uma carta, endereçada ao amigo Ramalho Ortigão, de Newcastle, em cujas linhas

\footnotetext{
2 Em 17 de maio de 1877, Eça mandava a Chardron os primeiros capítulos de $O$ primo Basílio e, em 5 de outubro, os últimos.
} 
Eça esboça uma crítica bastante rigorosa sobre o romance e sobre si mesmo, enquanto escritor:

Eu por aqui - não fazendo, não pensando, não vivendo senão Arte. Acabei O Primo Basílio - uma obra falsa, ridícula, afectada, disforme, piegas e papoulosa - isto é tendo a propriedade da papoula: - sonoloficiente. De resto Você lerá - isto é dormirá. Seria longo explicar como eu - que sou tudo menos insípido - pude fazer uma obra insípida: - mas essa explicação era ela mesma outro romance et bien autrement poignant et singulier. A propósito que lhe pareceu a Você o trecho publicado no Diário da Manhã? Idiota, não é verdade? Ce n'est pas ça. Ce n'est pas ça, du tout. O estilo tem limpidez, fibra, transparência, precisão, netteté. Mas a vida não vive. Falta a poigne. Os personagens - e Você verá - não têm a vida que nós temos: são inteiramente des images découpées - mas têm uma musculatura gelatinosa. Oscilam, fazem beiços como os queijos da serra, espapam, derretem. Há inquestionavelmente - algumas cenas, alguns traços correctos: e há maravilhas de habilidade: mas de pequena habilidade, da habilidade de métier; enfim sou uma besta. Nunca hei de fazer nada como o Père Goriot: e se Você soubesse a melancolia em tal caso, da palavra nunca! Não falo naturalmente do Primo Basílio: isto é uma ninharia abaixo dum crítico de Penafiel: mas mesmo este novo romance ${ }^{3}$ de que estou tão contente - não dá, não sai. Faço mundos de cartão... não sei fazer carne nem alma. Como é? Como será? E todavia não me falta o processo: tenho-o superior a Balzac, a Zola e tutti quanti. Falta a coisinha dentro: a pequena vibração cerebral - sou uma irremissível besta! (EÇA DE QUEIROZ apud BERRINI, 2000: 319-320)

Parte do processo de redação de Eça é descrito por seu filho, José Maria d'Eça Queiroz (1888-1928), na introdução de $A$ Capital, quando da sua publicação póstuma em 1925. Quando aparecia a ideia para algum romance, Eça concebia, primeiramente, um plano inicial de poucas páginas, com o tema, episódios, apresentação das personagens, desenvolvimento reduzido e desfecho. O romance era apresentado no início em linhas gerais. Posteriormente, o plano era inteiramente recopiado e, durante este processo, Eça desenvolvia a ação, dava corpo às personagens, revia algumas posturas críticas, e as atenuava. Então, vinham as provas e novas correções, desenvolvimentos e emendas apareciam, em um trabalho praticamente infindável. Eça parecia nunca ficar satisfeito, mesmo após a publicação dos romances. Todavia, apresentava ao amigo Ramalho Ortigão grandes expectativas com relação ao romance no qual trabalhava:

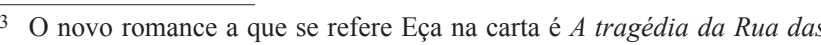
Flores.
}

\begin{abstract}
Mais Dieu, je crois que dans ce moment-ci je prends une petite révanche passablement étincelante. É o novo livro que estou a fazer - isto é: a concluir quase. Desse há-de Você gostar, e não há-de dormir. Ah não, dormir é que Você não há-de: insultar-me, desesperarse, revoltar-se, arrepelar-se, chamar-me crápula, isso sim. Mas dormir! Estou-lhes a preparar uma! Esfrego daqui as mãos, com um jubilozinho perverso. Espero que será publicado logo depois do Primo Basílio. (EÇA DE QUEIROZ apud BERRINI, 2000, p. 320)
\end{abstract}

Eça afiança, novamente, estar por concluir o romance que possuía em mãos e em outra carta para o seu editor, datada do final do mês, do dia 21 de novembro, reafirma seu julgamento sobre a obra: "O primeiro número está quase concluído: é, creio, o romance melhor e mais interessante que tenho escrito até hoje. A este segue-se na ordem dos trabalhos, se Deus quiser, $O$ milagre do Vale de Reriz" (EÇA DE QUEIROZ, 1979, v. III, p. 9-10).

O curioso é que este primeiro volume "quase concluído" acabou por receber o título de $A$ tragédia da Rua das Flores e só foi publicado postumamente em 1980. Os motivos que levaram Eça a abandonar este manuscrito são até hoje apenas suposições. A última referência feita a esse manuscrito data de um ano após, em uma correspondência de 28 de novembro de 1878 . Na missiva endereçada a Ramalho Ortigão, Eça discorria a respeito de um projeto de colaboração para o jornal brasileiro Gazeta de Notícias do Rio de Janeiro, dirigida por Ferreira de Araújo (1848-1900):

\footnotetext{
Eu tenho justamente um romance que estava à espera de vez: escrevi-o para ser a primeira parte das Cenas, mas além de ser mais volumoso do que o plano das Cenas comporta não me servia artisticamente como introdução às Cenas. Foi por isso que o substituí pela Capital, que é mais um trabalho de generalidade. O assunto é grave - incesto; mas tratado com tanta reserva, que não choca. Os amores de um lindo moço, título pretensiosamente medíocre. Poderei, pour la circonstance, chamar-lhe: $O$ Brasileiro; o herói é-o. Como arte tem tipos de que gosto - tratados numa nova maneira, a contornos grossos, de forte destaque; incidentes curtos, muito adaptáveis ao folhetim enfim, o que justamente convém. Que a Gazeta faça a sua proposta. (EÇA DE QUEIROZ apud MEDINA, 1980, p. 29)
}

Ora se Eça de fato se referia ao manuscrito d' $A$ tragédia, este estaria longe de estar "quase concluído" e "à espera" de publicação. Fora a indefinição do título, dizer que o herói era um brasileiro é uma inverdade. Como estratégia, o escritor poderia muito bem ter inventado isso, pensando que, se o projeto se vendesse, poderia fazer as devidas adaptações posteriormente. Mas 
isso não aconteceu e o manuscrito que foi publicado em 1980 guarda as antigas feições, sem nenhuma tentativa de converter Vítor da Silva (na verdade, da Ega) em um brasileiro.

A seguir cessam completamente as referências e alusões ao manuscrito, que, segundo os críticos da obra queiroziana, seria reaproveitado, enquanto ideia temática, no romance Os Maias, publicado em $1888^{4}$. Alfredo Campos Matos (1988) apresenta uma possível razão para Eça não ter publicado o manuscrito:

Esboçada $A$ tragédia, Eça lança-se à redacção d'A Capital (1878), que irá depois abandonar para se entregar por inteiro a Os Maias, cuja concepção se supõe ser de 1880. Para A Capital transferirá algumas personagens: o cantor Sarrotini, o poeta Roma, Padilhão, Meirinho e Joana Coutinho; para $O$ Conde de Abranhos (redigido em 1878-1879?) passará o episódio do prego que defende a cadeira do Dr. Caminha, em que Dâmaso Mavião se vai espetar (n' $O$ Conde de Abranhos a cadeira pertence ao Dr. Pimentel e quem nela se espeta é o desembargador Amado); para Os Maias passará Dâmaso, o barão de Markstein (n'Os Maias Steinbroken), o brasileiro Gomes, que traz Genoveva a Lisboa (n'Os Maias Castro Gomes). Estas transferências impedirão que retome algum dia a obra assim deliberadamente esvaziada de personagens e episódios. (MATOS, 1988, p. 909)

Vale lembrar, contudo, que o reaparecimento de certas personagens em mais de um romance, era prerrogativa das Cenas. Assim, não parece ser suficiente essa justificativa proposta por Campos Matos para a não publicação do texto. A 28 de fevereiro de 1878 a Livraria Chardron, do Porto, lançava a público a primeira edição de $O$ primo Basílio. Os três mil exemplares esgotaram-se rapidamente em três meses e "em abril, já amplamente lido no Rio de Janeiro, aqui provocava polêmica nos jornais e ensejava até ameaças de bordoada" como descreve Arnaldo Faro, no livro Eça e o Brasil (1977). Em duas cartas, para destinatários diferentes, Eça teceu comentários valorosos a respeito das críticas, da estética realista e das suas intenções literárias ao escrever o livro. Estes textos são fundamentais, uma vez que expressam as opiniões pessoais do escritor a respeito do movimento realista, bem como explanam as concepções artísticas das quais fazem parte o projeto das Cenas. A primeira missiva, endereçada a Teófilo Braga (1843-1924), data de 12 de março de 1878 :

\footnotetext{
4 É indiscutível o grau de parentesco entre as duas obras, todavia cada romance deve ser abordado segundo as suas características próprias: enredo, personagens, meio social e espacial, estratégia narrativa etc., uma vez que a não ser pela temática do incesto involuntário e certos episódios coincidentes, as obras divergem bastante entre si.
}

[...] a sua aprovação foi para mim uma agradável surpresa, e todavia a sua aprovação é mais ao processo que ao assunto, e Você vendo-me tomar a família como assunto, pensa que eu não devia atacar esta instituição eterna, e devia voltar o meu instrumento de experimentação social contra os produtos transitórios que se perpetuam além do momento que os justificou, e que, de forças sociais, passaram a ser empecilhos públicos. Perfeitamente: mas eu não ataco a família - ataco a família lisboeta - a família lisboeta produto do namoro, reunião desagradável de egoísmos que se contradizem, e, mais tarde ou mais cedo, centro de bambochata. O primo Basílio apresenta, sobretudo, um pequeno quadro doméstico, extremamente familiar a quem conhece bem a burguesia de Lisboa: a senhora sentimental, mal-educada, nem espiritual (porque, cristianismo, já o não tem; sanção moral da justiça, não sabe o que isso é) arrasada de romance, lírica, sobreexcitada no temperamento pela ociosidade e pelo mesmo fim do casamento peninsular, que é ordinariamente a luxúria, nervosa pela falta de exercício e disciplina moral, etc., etc. - enfim, a burguesinha da Baixa. Por outro lado, o amante - um maroto, sem paixão nem a justificação da sua tirania, que o que pretende é a vaidadezinha de uma aventura e o amor grátis. Do outro lado, a criada, em revolta secreta contra a sua condição, ávida de desforra. Por outro lado ainda, a sociedade que cerca estes personagens - o formalismo oficial (Acácio), a beatice parva de temperamento irritado (D. Felicidade), a literaturinha acéfala (Ernestinho), o descontentamento azedo e o tédio da profissão (Julião), e às vezes, quando calha, um pobre bom rapaz (Sebastião). Um grupo social, em Lisboa, compõe-se, com pequenas modificações, destes elementos dominantes. Eu conheço vinte grupos assim formados. Uma sociedade sobre estas falsas bases, não está na verdade: atacá-las é um dever. E neste ponto $O$ primo Basílio não está inteiramente fora da arte revolucionária, creio. Amaro é um empecilho, mas os Acácios, os Ernestos, os Saavedras, os Basílios, são formidáveis empecilhos: são uma bem bonita causa de anarquia no meio da transformação moderna: merecem partilhar com o padre Amaro da bengalada do homem de bem. (EÇA DE QUEIROZ, 1979, v. III, p. 516-517)

A representação crítica da sociedade portuguesa de sua época era, para Eça, uma das qualidades presentes no livro, um dos seus méritos. A explicação das personagenstipo estava em completa coerência com os princípios deterministas de Taine que propagava que a arte deveria ater-se à representação dos caracteres mais profundos, perenes e essenciais dos indivíduos e das coisas. Assim, quando Eça explicou e definiu a personagem Luísa como sendo a "burguesinha da Baixa", o escritor expôs seu local de origem como um fator determinante na formação da sua personalidade e do seu comportamento. Logo, o meio social em que cresceu, a educação recebida dos 
seus pais e depois, do colégio, talharam o seu espírito fraco, facilmente impressionável, portanto corruptível. Na segunda carta, de 30 de março de 1878, endereçada a Rodrigues de Freitas (1840-1896), Eça defende os princípios estéticos do realismo:

Não é menos para agradecer a defesa que Vossa Senhoria faz da originalidade lisboeta do «Primo Basílio». Não me parece, com efeito (e creio que todos os espíritos lúcidos estão de acordo) que o romance seja uma imitação de Zola; é possível que, aqui e acolá, haja dessas vagas similitudes de acção - naturais quando se estuda um meio quase análogo, por um processo quase paralelo: mas a verdade é que eu procurei que os meus personagens pensassem, decidissem, falassem e actuassem como puros lisboetas, educados entre o Cais do Sodré e o Alto da Estrela; não lhes daria nem a mesma mentalidade, nem a mesma acção se eles fossem do Porto ou de Viseu; as individualidades morais variam de província a província - mas no meio lisboeta que escolhi, creio que elas são lógicas, exactamente derivadas e perfeitamente correspondentes. [...]

O que lhe agradeço profundamente é a sua defesa geral do Realismo. Os meus romances importam pouco; está claro que são medíocres; o que importa é o triunfo do Realismo - que, ainda hoje méconnu e caluniado, é, todavia a grande evolução literária do século, e destinado a ter na sociedade e nos costumes uma influência profunda. O que queremos nós com o Realismo? Fazer o quadro do mundo moderno, nas feições em que ele é mau, por persistir em se educar segundo o passado; queremos fazer a fotografia, ia quase a dizer a caricatura do velho mundo burguês, sentimental, devoto, católico, explorador, aristocrático, etc. E apontando-o, ao escárnio, à gargalhada, ao desprezo do mundo moderno e democrático - preparar a sua ruína. Uma arte que tem este fim - não é uma arte à Feuillet ou à Sandeau. É um auxiliar poderoso da ciência revolucionária. (EÇA DE QUEIROZ, 1983, v. 1, p. 142)

Nesta segunda missiva, mais formal, uma vez que Freitas não era um amigo próximo, como Teófilo Braga, Eça humildemente exalta a relevância do triunfo do realismo que, em suas palavras, seria mais importante que o sucesso de $O$ primo Basílio. Ao discorrer sobre os objetivos literários do movimento, o autor ressalta a crítica veemente aos costumes burgueses como uma arma poderosa contra os problemas sociais vigentes na época. Aproveitando o sucesso de $O$ primo Basílio, o escritor dá prosseguimento ao projeto das Cenas e em correspondência a Chardron de 13 de junho de 1878, Eça escreve que esperava remeter por aqueles dias $A$ Capital! e quinze dias depois, em outra epístola, de 28 de junho de 1878, explica os procedimentos que o editor deveria tomar ao anunciar as Cenas e com quais títulos ela seria constituída:
Não acho título melhor do que Cenas Portuguesas. Podia também ser Cenas da Vida Portuguesa. Se tiver ocasião de escrever ao Ramalho, consulte-o sobre isto. Julgo conveniente e desejo que só anuncie em 'preparação' os três primeiros contos: o primeiro deve ser A Capital. Eis os títulos dos contos, se Deus quiser que tudo corra bem: I - A Capital; II - O milagre do Vale de Reriz; III - A linda Augusta; IV - O Rabecaz; V-O Bom Salomão; VI-ACasa No 16; VII-O Gorjão, Primeira Dama; VIII - A Ilustre Família Estarreja; IX -AAssembléia da Foz; X - O Conspirador Mathias; XI - História de um grande homem; e XII - Os Maias. Seria ridículo anunciar mais de três; o primeiro em todo caso, é A Capital que está arranjada... (EÇA DE QUEIROZ, 1979, v. III, p. 10) ${ }^{5}$

Muitos dos nomes da lista ficaram somente como esboços e nunca chegaram a constituir manuscritos acabados. Porém, a listagem mostra claramente um plano de trabalho maior, que Eça, de algum modo, abraçou por toda a sua vida. Alguns títulos se aproximam muito de outros trabalhos desenvolvidos por ele. No livro $A$ Construção da narrativa queirosiana, Carlos Reis (1989), ao realizar o levantamento e análise do espólio deixado por Eça, pertencente hoje aos arquivos da Biblioteca Nacional em Lisboa, através da leitura dos vários manuscritos, apresenta a hipótese de A Ilustre Família Estarreja ter se transformado em A Ilustre Casa de Ramires e História de um grande homem em $O$ Conde de Abranhos. Estas informações são muito valiosas, pois demonstram que o projeto das Cenas, apesar de não ter ido adiante como uma coleção lançada em espaços regulares de tempo, nunca teve seu conceito abandonado por completo pelo autor. Prova disso é o caso de A Ilustre Casa de Ramires, que só teve o manuscrito desenvolvido e lançado quase vinte anos depois, em 1897, já nos últimos anos de vida do escritor.

Eça dá alguns indícios em correspondência ao amigo Ramalho Ortigão, de 08 de abril de 1878 , sobre os possíveis motivos que o fizeram desistir, posteriormente, do projeto de lançar as Cenas como uma coleção regular de títulos:

Eu trabalho nas Cenas Portuguesas, mas sob a influência do desalento. Convenci-me de que um artista não pode trabalhar longe do meio em que está a sua matéria artística: Balzac não poderia escrever a Comédia Humana em Manchester, e Zola não lograria fazer uma linha dos Rougon em Cardife. Eu, não posso pintar Portugal em Newcastle. Para escrever qualquer página, qualquer linha, tenho de fazer dois violentos esforços: desprender-me inteiramente da impressão

\footnotetext{
5 Alguns dos títulos mencionados já haviam sido citados em carta anterior de novembro de 1877. Dois deles desapareceram da listagem ou foram renomeados: $O$ Bacharel Sarmento, que abordaria o tema da educação e Sóror Margarida, que abordaria a monogamia religiosa.
} 
que me dá a sociedade que me cerca e evocar, por um retesamento da reminiscência, a sociedade que está longe. Isto faz que os meus personagens sejam cada vez menos portugueses - sem por isso serem mais ingleses: começam a ser convencionais; vão-se tornando 'uma maneira'. Longe do grande solo de observação, em lugar de passar para os livros, pelos meios experimentais, um perfeito resumo social, vou descrevendo, por processos puramente literários e a priori, uma sociedade de convenção, talhada de memória. De modo que estou nesta crise intelectual: ou tenho de me recolher ao meio onde posso produzir, por processo experimental - isto é, ir para Portugal - ou tenho de me entregar à literatura puramente fantástica e humorística. (EÇA DE QUEIROZ, 1979, v. III, p. 519-520)

Em carta a Ernesto Chardron de 04 de agosto de 1878, Eça, de alguma forma, resolve continuar o trabalho no primeiro título das Cenas. Explica que $A$ Capital! já estava escrita, a cópia ia muito adiantada e que esperava remeter o manuscrito em breve. Depois, complementa:

Estou bastante contente com A Capital! - ainda que receio que se repitam as acusações de escândalo, desta vez mais sérias, porque não se trata de mulheres, nem de amores, mas são pinturas um pouco cruéis da vida literária em Lisboa (jornalistas, artistas, etc.). Deus queira que ninguém tenha tolice de se julgar ferido. (EÇA DE QUEIROZ, 1979, v. III, p. 11)

Mas o que era para ser um romance de no máximo 200 páginas se transforma em um volume estimado de 400 a 420 páginas impressas e, neste momento, pelo interesse que o assunto suscitava e pela busca sempre incessante da forma perfeita, Eça começa a se desentender com seu editor.

Em outubro de 1878, é lançada a segunda edição revista de $O$ primo Basilio, e Chardron resolve lançar, também, a segunda edição de $O$ crime do padre Amaro, devido à morosidade de Eça em remeter os primeiros manuscritos das Cenas, mas continua pressionando o autor a dar prosseguimento com o trabalho. Como resposta, Eça esclarece em missiva de 12 de outubro que o manuscrito estava "pronto até a última linha", mas que não estava revisado e propõe o seguinte:

Mas que havemos de fazer com minuciosidade - e se revejo o Padre Amaro não posso ocupar-me de $A$ Capital. Eu não sou como César, para escrever duas cartas - ou dois livros - a um tempo. Parece-me pois, que o melhor, o mais prudente, o mais hábil, será fazer toda a força sobre o Padre Amaro, e deixar A Capital para o fim do ano. (EÇA DE QUEIROZ, 1979, v. III, p. 11)

Por este tempo, também estavam sendo impressas as primeiras provas de $A$ Capital, cerca de 80 páginas apenas, que correspondiam aos três primeiros capítulos.
O escritor, na mesma epístola, propõe uma estratégia de ação ao editor:

Temos agora O Primo Basílio. Bem. Depois duma pausa, para os fins de Novembro, lançamos o Padre Amaro. Fazemos então outra pausa, maior, como quando se quer produzir uma sensação - e atiramos-lhe com A Capital. Não lhe parece isto mais razoável? As folhas de $A$ Capital impressas podem ficar por algum tempo armazenadas, esperando. (EÇA DE QUEIROZ, 1979, v. III, p. 11)

Contudo, não foi bem assim que as coisas aconteceram. Ao preparar a segunda edição de $O$ crime do padre Amaro, Eça praticamente o reescreve, alterando completamente a forma do texto sem perder a concepção primitiva do livro ${ }^{6}$. Isso the tomou muito mais tempo do que previa. Mesmo a revisão de $O$ primo Basílio foi bastante morosa, como confessou o próprio escritor a Chardron. Eça levava cerca de 2 a 3 dias para revisar cada folha impressa! Outro exemplo significativo dessas inúmeras revisões, correções e ampliações são as 80 folhas impressas de $A$ Capital! que se transformaram em cerca de 200 páginas, após passarem pelo exigente crivo do escritor.

A verdade é que Eça era extremamente minucioso com seu trabalho, tanto na concepção quanto na apresentação. Sempre que remetia algum manuscrito a Chardron, aguardava as provas de impressão, e as corrigia, emendava, chegava a colar tiras de papel escritas nas laterais das folhas e, não raras vezes, pedia outras provas, até ficar convictamente satisfeito com o resultado (observar a Fig. 1, adiante).

Esse processo devia se prolongar por meses, já que, desde 1875, Eça vivia na Inglaterra (primeiro em Newcastle e, a partir de julho de 1878, em Bristol) e seu editor, Ernesto Chardron, residia no Porto. Esse procedimento foi motivo de vários desentendimentos, como é possível perceber em carta de 10 de novembro de 1878, e até de discussões mais sérias como ainda será demonstrado. Eça escreve:

Enquanto às provas de $A$ Capital, é outro caso. Eu mesmo ao rever as primeiras provas direi se quero ou não segundas, e espero poder quase sempre dispensar as segundas. A pressa que V. Ex. ${ }^{a}$ tem - e que eu agora tenho também - não é todavia tão urgente que me leve a arriscar os meus créditos pela apresentação dum trabalho incorreto. V. Ex. ${ }^{a}$ sabe como é o meu estilo: não sendo revisto com escrúpulo, é 'trapalhada'. (EÇA DE QUEIROZ, 1979, v. III, p. 11)

\footnotetext{
6 No prefácio da segunda edição de $O$ crime do padre Amaro, Eça escreve o seguinte: "Muitos capítulos foram reconstruídos linha por linha; capítulos novos acrescentados; a ação modificada e desenvolvida; os caracteres mais estudados, e completados; toda a obra enfim mais trabalhada". (EÇA DE QUEIROZ, 1979, v. I, p. 32)
} 


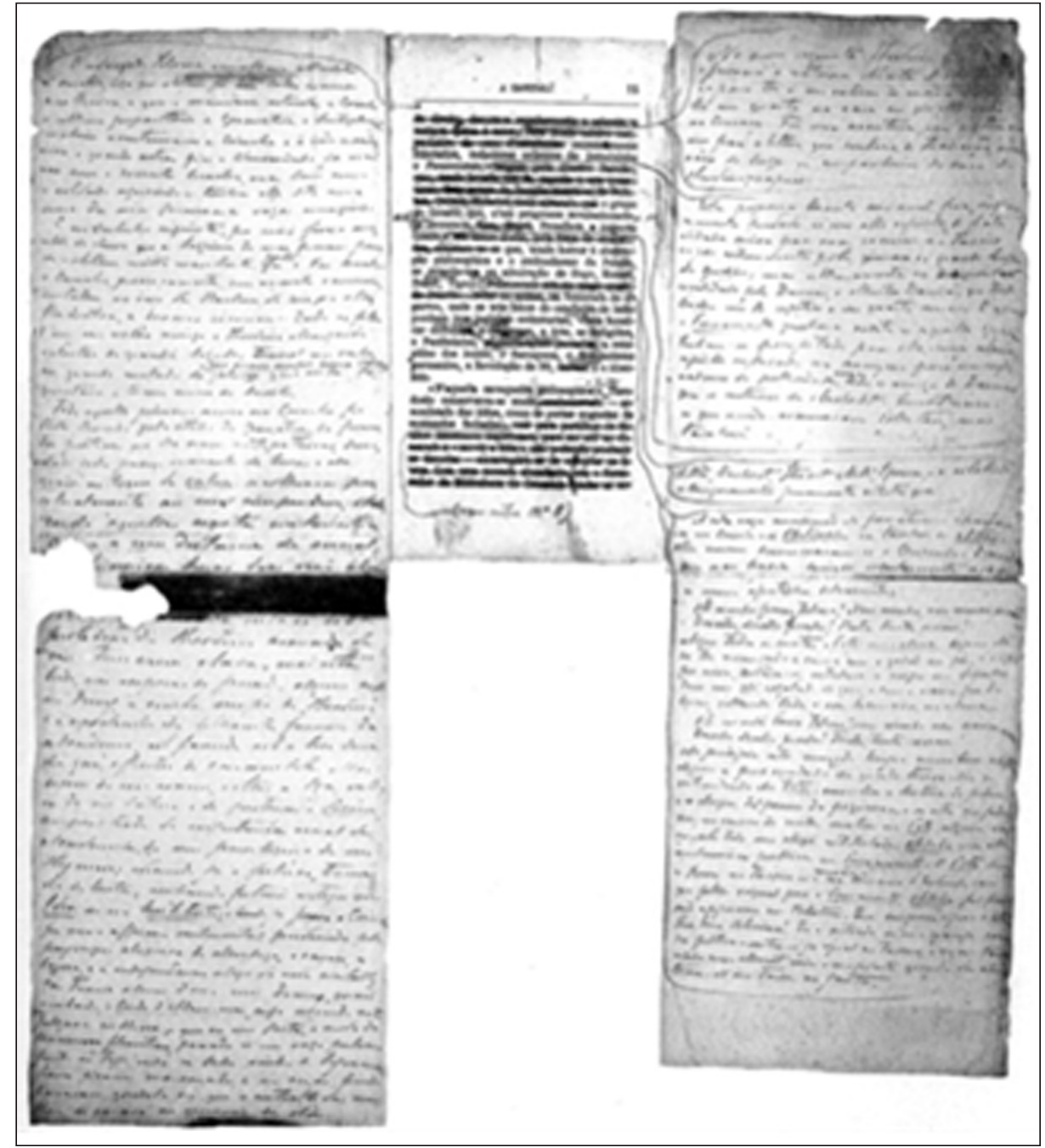

Figura 1. Trecho de manuscrito de A Capital! (começos duma carreira) referente ao Capítulo I, linhas 338-403.

FONTE: EÇA DE QUEIROZ, José Maria. A Capital! (começos duma carreira). Edição crítica preparada por Luiz Fagundes Duarte. Lisboa: Imprensa Nacional-Casa da Moeda, 1992, folhas anexas entre as páginas 32 e 33
De qualquer forma, talvez por exigência do editor, Eça continua revendo as provas de $A$ Capital! e de $O$ Crime do Padre Amaro paralelamente, quando lhe surge a ideia de um novo livro: A Batalha do $\mathrm{Caia}^{7}$, mencionado na correspondência de 23 de dezembro de 1878 :

Rogo que mandem as folhas impressas do Amaro e Capital: sem elas é-me quase impossível fazer a revisão do restante. Aguardo com impaciência, de Lisboa, uma resposta sobre A Batalha do Caia... (...) Todo o meu empenho é desembaraçar-me de Amaro e de $A$ Capital o mais depressa possível, e se a coisa se resolver bem dedicar-me à Batalha. Isso é que é livro! (EÇA DE QUEIROZ, 1979, v. III, p. 12)

\footnotetext{
7 Sobre $A$ Batalha do Caia, pouco se sabe, pois apenas existe um plano inicial do livro e que mais tarde se transformou no conto $A$ Catástrofe. $\mathrm{Na}$ introdução da publicação de $A$ Capital!, organizada pelo filho de Eça, José Maria, este escreve sobre o tema do livro: "Portugal, invadido, vencido, batido, ia encontrar nas humilhações da derrota e da ocupação estrangeira, o renascimento da fé e das energias perdidas, que um dia provocariam o nosso ressurgimento nacional" (EÇA DE QUEIROZ, 1979, v.. III, p. 12).
}

A ideia do livro não prossegue, pelo menos, não naquele momento. Em 08 de junho de 1879, ou seja, seis meses depois, uma outra carta surpreende: nela, Eça pergunta a Chardron se ele teria o interesse de "publicar imediatamente" um livro de 200 a 250 páginas. Escreve ainda que este novo trabalho não o impediria de continuar com a revisão do Padre Amaro mais incisivamente e com A Capital!, mais devagar. Em carta, datada de 23 do mesmo mês, esclarece sobre o novo livro, $O$ Conde de Abranhos, e sobre o assunto que abordava: uma espécie de biografia, de um indivíduo imaginário, escrita também por um sujeito imaginário. Tal livro não interessou a Chardron e Eça o coloca de lado, voltando a trabalhar nas revisões.

O passar do tempo leva ambos a um novo desentendimento. Chardron reclamava a revisão do Padre Amaro e o direito de publicação de A Capital!. Eça responde em carta de 20 de outubro de 1879:

(...) o nosso último acordo, proposto em carta de V. Ex. ${ }^{\text {, }}$, era que se publicasse o Amaro em fins de 
Outubro ou começos de Novembro, e A Capital em princípios do ano. É a este acordo que eu me cinjo e, para o cumprir, trabalho noite e dia!... De $A$ Capital nem falemos: vendi-lhe um livro de 200 páginas por 20 libras e estou a fazer um volume de 600 ! - Pode V. Ex. ${ }^{a}$, se quiser, publicar $A$ Capital, ou os capítulos que aí tem de $A$ Capital. Eu não tenho poder para lho impedir. São apenas três capítulos que não significam nada e que, publicados, pareceriam uma mistificação, pois a ação do romance não aparece neles e apenas se apresentam os personagens. Se o fizer, eu declaro pela imprensa que isso é apenas o começo de um romance que tem mais de 600 páginas e que o público deve portanto esperar que o romance seja publicado inteiro... (EÇA DE QUEIROZ, 1979, v. III, p. 13)

Novas referências ao romance aparecem em 15 de novembro:

Vão provas e amanhã original. Querendo Deus, espero ter por estas semanas o Amaro pronto. Faltam apenas duas folhas. Em seguida, atiro-me à Capital com toda a força. Peço pois, mande pela volta do correio as folhas de $A$ Capital que aí tem de impressão inutilizada, para eu fazer algumas emendas. Diga-me também em que formato a vai imprimir. (EÇA DE QUEIROZ, 1979, v. III, p. 13)

Com relação a "impressão inutilizada", Eça refere-se àquelas 80 páginas correspondentes ao início do romance. Em 23 de dezembro Eça remete de Bristol novas provas corrigidas e parece estar novamente otimista quanto à publicação do romance:

Remeti provas de $A$ Capital, e peço todas as suas habilidades de reclamo para este romance. Merece bem, creio, que se faça alguma coisa por ele. Mais bem escrito até aqui que $O$ primo Basílio, contendo no meio o que o público talvez chame um escândalo político, e no fim o que pode parecer um escândalo de moral - é natural que excite a curiosidade. Esperemos que assim seja. Eu, naturalmente, não tive intenção de o fazer escandaloso. O público é que na sua teima de ver em tudo escândalo o pode considerar tal. Que a revisão seja bem feita, é o que recomendo... (EÇA DE QUEIROZ, 1979, v. III, p. 14)

Este intrincado processo de revisão se estende e somente em meados de 1880 é publicada a segunda edição de $O$ Crime do Padre Amaro, edição essa que vinha acompanhada por um reclamo da casa editorial que noticiava a próxima publicação de $A$ Capital! em volume. Mas nem com este anúncio Chardron conseguiu obter o original da obra corrigido e terminado. Eça diz que continuava a trabalhar em $A$ Capital!, que naquele momento era composta de duas partes: a primeira constituída das 80 páginas impressas, revistas e emen- dadas pelo escritor, que totalizavam, no fim, cerca de 200 páginas e a segunda constituída pelo restante dos capítulos, em manuscritos. Dizia que estava "copiando" a segunda parte do manuscrito, o que no linguajar de Eça pode-se traduzir como "reescrevendo". Diz:

Enquanto à Capital não me zanga a sua impaciência, porque a minha é ainda maior. Mas V. Ex. ${ }^{a}$ não me compreendeu. Não houve fausse alert. Como lhe disse, a segunda parte está pronta, e não a mando porque estou a copiá-la. Comprenez-vous maintenant? Deste modo evito as segundas provas. Imagina que estou a copiá-la por meu prazer e divertimento? Não! É para apressar o trabalho. Mas se ainda assim não acreditar na minha ardente vontade de pôr o livro na rua em dois meses - então vou daqui por diante mandar-lhe o original, como ele sai, crivado de emendas - e na tipografia que se avenham. Creia que faço tudo o que é possível para dar A Capital para meados de Abril, ou antes, querendo Deus... (GUERRA DA CAL, 1975, tomo $1^{\circ}$, p. 371)

Há uma grande lacuna nas correspondências trocadas entre Eça e o seu editor. Sabe-se que o primeiro semestre de 1880 o romancista passa em Portugal, a mais larga estada no país desde que iniciou a sua carreira diplomática. Talvez este período justifique a missiva, de 11 de agosto, remetida a Chardron, quando do seu retorno para Bristol, onde menciona, pela primeira vez, estar trabalhando na redação de Os Maias: "Logo que termine Os Maias, que estão por dias, estou livre para me entregar todo à conclusão de $A$ Capital, que irá depressa, querendo Deus..." (EÇA DE QUEIROZ, 1979, v. III, p. 14).

O que será que fez com que Eça, mais uma vez, trabalhasse $A$ Capital em segundo plano? Insatisfação com a obra? Cansaço das cobranças de Chardron? Falta de tempo? Uma coisa é certa: se Eça não estivesse satisfeito com a obra, com o andamento do trabalho, ele poderia tê-lo colocado de lado e feito uma nova negociação com o editor. Quanto às cobranças, Eça sabia como contornálas. De forma que só resta uma possível explicação: o romance, apesar de despertar muito o interesse de Eça, nunca alcançou o estágio que este gostaria, não atingiu a forma precisa e extremamente crítica que seu autor desejava. É sabido também que Eça, juntamente com seu ofício de escritor, levava muito a sério o trabalho no Consulado, e ainda se dedicava à publicação de artigos em jornais. É deste período também a escrita e publicação em onze folhetins da novela $O$ Mandarim, para o Diário de Portugal, e o início de longos anos de colaboração com a Gazeta de Notícias, jornal do Rio de Janeiro.

Quanto a Os Maias estarem "por dias", sabe-se que o processo de escrita e revisão levou outros oitos anos até a publicação em 1888. Uma lacuna de cerca de seis meses na correspondência entre Eça e Chardron impossibilita um 
maior conhecimento sobre o período. A obra A Capital! só é mencionada novamente em 16 de janeiro de 1881 :

Tem V. Ex. ${ }^{\text {a }}$ razão, mil vezes razão a propósito de $A$ Capital! Mas que quer? Meti-me nesta empresa de Os Maias, que deviam ser apenas uma novela e se tornaram um verdadeiro romance! E tenho posto todo o meu tempo a trabalhar nele. Felizmente vejo para breve o fim desta obra - e então, em pouco tempo, querendo Deus, a Capital estará pronta. Porque não creia que não tenho também trabalhado nela, aqui e além, mas trabalho casual que pouco adianta. Os Maias absorveram-me. Findos eles, porém, umas poucas de semanas, bem aproveitadas bastarão para pôr a Capital em termos de impressão. (GUERRA DA CAL, 1975, tomo $1^{\mathrm{o}}$, p. 371-372)

Todavia, em carta para o amigo Ramalho Ortigão, de 20 de fevereiro, Eça parece antever o triste fim que levaria A Capital:

Quando eu estive em Lisboa, o Malheiro pediu-me que escrevesse para o Diário [de Portugal] um romance: apelou urgentemente para a nossa velha amizade, e deu-me razões determinantes. Para o satisfazer, interrompi a Capital, estragando-a para sempre, creio eu, porque vejo agora que não poderei recuperar o fio de veia e de sentimento em que ela ia tratada, e faltei aos meus compromissos com o Chardron. Apenas o trabalho ia a meio, reconheci que tinha diante de mim um assunto rico em caracteres e incidentes e que necessitava um desenvolvimento mais largo do romance. Comuniquei isto ao Malheiro, que se alegrou - e para fazer pacientar os leitores do jornal, presenteei o Diário com uma novela: O Mandarim (grátis!). (GUERRA DA CAL, 1975 , tomo $1^{\circ}$, p. 372 )

O trabalho que «ia a meio» era decerto Os Maias e Eça logo percebeu que não conseguiria impor ao tema os limites necessários para uma novela. Assim, para não desabonar o seu amigo, oferece-lhe como substituto $O$ Mandarim. Entre 28 de maio e 02 de junho de 1881 são publicados na Folha Nova do Porto quatro folhetins extraídos de $A$ Capital! com o título A Herança. Posteriormente, em 1883, no Diário da Manhã de Lisboa, de 11 de outubro, é publicado um extrato do livro A Capital! retirado da Folha da Tarde. Outra interrupção na correspondência entre Eça e Chardron leva a última menção do romance A Capital, já em 16 de março de 1883 :

V. Ex. ${ }^{a}$ tem razão em tudo o que diz a respeito do seu direito de editar A Capital. Esse direito adquiriu-o de fato, tendo começado a impressão de uma espécie de novela que tinha esse título e que originou um romance. Contudo, é intenção minha que, querendo Deus, seja ainda V. Ex. ${ }^{a}$ que edite $A$ Capital. Tudo está em nos entendermos... (EÇA DE QUEIROZ, 1979, v. III, p. 15)
Esse entendimento, ao que parece, nunca ocorreu e sobre o novo acordo entre Eça e Chardron não há outros esclarecimentos. Depois de cinco anos de trabalho, o manuscrito de $A$ Capital! é posto de lado. As razões que levaram Eça a não publicar posteriormente o trabalho de anos são apenas suposições. A mais provável é que o romance não havia atingido a concepção idealizada e desejada por Eça. Os longos anos de trabalho nunca intimidaram o escritor, pois seu processo criativo estava intimamente ligado à longa e árdua maturação de textos cuja publicação distava por vezes muitos anos do momento em que eram concebidos e anunciados. Já foi mencionada aqui a longa redação de Os Maias, que constava como último título das Cenas portuguesas em 1878 e que só foi publicado em 1888, dez anos depois.

Prova disso, de que $A$ Capital! não se encontrava em uma forma tolerável para o escritor, é a carta endereçada ao jornalista e amigo Cristóvão Aires (1853-1930), interessado em publicar algum material do escritor no Jornal do Comércio, de sete de julho de 1884. Cerca de um ano após a última referência feita por Eça sobre o romance $A$ Capital! em carta a Chardron, o autor esclarece:

Eu não tenho neste momento, na forja, senão dois trabalhos: Os Maias que estão vendidos ao Chardron, e meio impressos; e um trabalho, que se chama Relíquia e que pertence à Gazeta de Notícias do Rio de Janeiro. $A$ Capital é no estado atual uma massa informe de prosa, um grosso bloco de greda, donde levaria muito tempo a extrair uma obra viva. Vê, pois, meu caro Cristóvão Aires, que apesar do meu desejo, e da honra certa que seria para mim, em ter um estudo publicado no Jornal do Comércio - eu me vejo perante o seu pedido, como um mercador que tem os seus armazéns vazios, e a fazenda em mar, já vendida. (EÇA DE QUEIROZ, 1979, v. III, p. 527)

Extremamente severo com seus trabalhos, Eça não poupa nenhum de seus livros: todos, sem exceção, poderiam ser melhores, ou na escrita, ou na composição de alguma personagem, ou em algum outro ponto qualquer. Independentemente dos comentários da crítica, dos elogios dos amigos, do sucesso nas vendas, para Eça, algo sempre poderia ser diferente. Sobre A Capital! existe um outro testemunho interessante, em carta a Ramalho Ortigão, do primeiro semestre de 1878, ainda no início da redação:

Você leu o primeiro capítulo da Capital? Que lhe parece? A mim pareceu-me mau; e o resto do livro, você verá, pior; é frio, é triste, é artificial; é um mosaico laborioso; pode-se gabar a correção mas lamenta-se a ausência de vida; os personagens são todos empalhados - e tenho-lhes tanto ódio, que se eles tivessem algum sangue nas veias, bebia-lho. Sou uma besta: sinto o que devo fazer, mas não o sei fazer. (EÇA DE QUEIROZ apud MEDINA, 1980, p. 29) 
Essas autoavaliações, se assim as podemos chamar, referentes ao romance $A$ Capital!, não diferem do tom crítico utilizado pelo escritor ao comentar $A$ Relíquia $^{8}$ ou Os Maias $^{9}$. Vale lembrar, também, que essa "insatisfação permanente" com o texto não impossibilitou a publicação dos referidos romances. Nestes termos, é possível questionar: por que, então, não aconteceu o mesmo com A Capital!? Por qual ou por quais motivo(s) o livro não foi publicado? Não existem respostas definitivas para estas perguntas e qualquer tentativa em respondê-las permanecerá sempre no campo das suposições. Porém, existem alguns indícios e fatos que limitam consideravelmente as possibilidades, dentre as quais, duas se destacam, sem que uma anule propriamente a outra:

1. Eça não conseguiu entrar em um acordo com seu editor. Neste caso, o motivo para a não publicação do romance seria de ordem financeira. Como o próprio autor escreveu, ele havia vendido por 20 libras uma novela de 200 páginas que se tornaram, no fim, um romance de 600 . Na última carta de 1883 esta ideia é reforçada, quando escreveu que Chardron realmente havia adquirido o direito sobre uma novela com este título, mas que depois ela havia se transformado em um romance. A distinção do escritor entre novela e romance para definir os dois estágios da obra, talvez o tenham levado a uma nova negociação de preço com o editor, ficando evidente que as 20 libras eram suficientes para pagar uma novela, mas não um romance daquele porte. É bom lembrar que a extensão de $A$ Capital! também não permitia sua publicação como folhetim, apenas como volume.

2. Eça não conseguiu talhar no romance a forma que almejava. Esta possível explicação já chegou a ser mencionada em alguns momentos e adquire um peso maior quando os processos de criação,

\footnotetext{
8 Sobre $A$ Relíquia escreve em carta de 02 de julho de 1887 a Luiz de Magalhães: "Eu por mim, salvo o respeito que lhe é devido, não admiro pessoalmente A Relíquia. A estrutura e composição do livreco são muito defeituosas. Aquele mundo antigo está ali como um trambolho, e só é antigo por fora, nas exterioridades, nas vestes e nos edifícios; é, no fundo, uma paráfrase tímida do Evangelho de S. João, com cenários e fatos de teatro; e falta-lhe ser atravessado por um sopro naturalista de ironia forte que daria unidade a todo o livro; D. Raposo, em lugar de se deixar assombrar pela solenidade histórica devia rir-se dos Judeus e troçar dos Rabis. O valor qualquer do livreco está no realismo fantástico da Farsa". Apud EÇA DE QUEIROZ, José Maria. Correspondência in Obras de Eça de Queiroz. Porto: Lello e Irmão Editores, 1979, v. III, p. 575.

9 Sobre Os Maias Eça escreveu o seguinte para Oliveira Martins, em 12 de junho de 1888: "Os Maias saíram uma coisa extensa e sobrecarregada, em dois grossos volumes! Mas há episódios bastante toleráveis. Folheiaos, porque os dois tomos são volumosos demais para ler. Recomendo-te o começo, as primeiras 100 páginas; certa ida a Sintra; as corridas, o desafio; a cena no jornal $A$ Tarde; e sobretudo o sarau literário. Basta ler isso, e já não é pouco. Indico-te para não andares a procurar através daquela imensa massa de prosa". In: EÇA DE QUEIROZ, José Maria apud BERRINI, Beatriz. Eça de Queiroz: Literatura e Arte. Uma antologia. Lisboa: Relógio d’Água, 2000, p. 335-336.
}

redação e consequente correção dos textos pelo escritor são levantados. Esta ideia é sustentada quando a carta a Cristóvão Aires, de 1884, já mencionada e transcrita, é analisada. Essa carta ilustra bem o posicionamento do escritor em relação à obra. Descontados os «exageros» críticos de Eça sobre os próprios romances, o que fica evidente é a sensação de insatisfação. A obra ainda não havia atingido todo o potencial que possuía e merecia, e, sem a aprovação do seu criador, o romance só foi publicado vinte e cinco anos após a morte do escritor.

No final da introdução de A Capital!, José Maria D'Eça de Queiroz, filho do escritor e organizador de parte da publicação póstuma dos inéditos mencionados, escreveu o seguinte:

Sabe-se apenas que em 1885 Ernesto Chardron adquire Os Maias vindo a falecer daí a pouco. Sucedem-lhe na casa Editora os Srs. Lugan \& Genelioux: trocam-se cartas, renovam-se contratos, mas de A Capital! nunca mais se fala. Depois publica-se $O$ Mandarim, imprimem-se Os Maias, lança-se A Revista de Portugal, aparecem as primeiras cartas de Fradique... Estavam definitivamente postos de parte todos estes trabalhos de mocidade: A tragédia da Rua das Flores, A Capital, o Alves, O Conde de Abranhos; e todo esse mundo que um momento vivera tão intensamente no espírito do artista, mergulha melancolicamente no esquecimento, e começa o seu longo sono de quarenta anos, no fundo de uma gaveta, sob a capa de poeira dos manuscritos desprezados. (D'EÇA DE QUEIROZ, 1979, v. III, p. 15)

Felizmente, estes trabalhos de mocidade foram publicados e todo esse rico período de trabalho e de processo criativo ficaram registrados nos diálogos epistolares do escritor onde, mais uma vez, podemos maravilharmos com as idiossincrasias da prosa queiroziana.

\section{Referências}

BERRINI, Beatriz. Eça de Queiroz: Literatura e Arte. Uma antologia. Lisboa: Relógio d'Água, 2000.

D'EÇA QUEIROZ, José Maria. Introdução In: A Capital in Obras de Eça de Queiroz. Porto: Lello e Irmão Editores, 1979. v. III.

EÇA DE QUEIROZ, José Maria. O crime do padre Amaro. In: Obras de Eça de Queiroz. Porto: Lello e Irmão Editores, 1979. v. I.

EÇA DE QUEIROZ, José Maria. Correspondência. In: Obras de Eça de Queiroz. Porto: Lello e Irmão Editores, 1979. v. III.

EÇA DE QUEIROZ, José Maria. Correspondência. Edição de Guilherme de Castilho. Lisboa: Imprensa Nacional-Casa da Moeda, 1983. v. 1. 
EÇA DE QUEIROZ, José Maria. A Capital! (começos duma carreira). Edição crítica preparada por Luiz Fagundes Duarte. Lisboa: Imprensa Nacional-Casa da Moeda, 1992.

FARO, Arnaldo. Eça e o Brasil. São Paulo: Nacional; EDUSP, 1977. (Brasiliana, 358).

GAZETA DE NOTÍCIAS, ano XIX, n. 193, 1893.

GUERRA DA CAL, Ernesto. Lengua y estilo de Eça de Queiroz. Apéndice. Bibliografía queirociana sistemática y anotada e iconografía artística del hombre y la obra. Coimbra: Por Ordem da Universidade, 1975. Tomo $1^{\circ}$.

MATOS, Alfredo Campos (Org. e Coord.). Dicionário de Eça de Queiroz. 2. ed. Lisboa: Caminho, 1988.
MATOS, Alfredo Campos. Eça de Queiroz/Emília de Castro - correspondência epistolar. 2. ed. Porto: Lello Editores, 1996. MATOS, Alfredo Campos. Suplemento ao dicionário de Eça de Queiroz. Lisboa: Caminho, 2000.

MEDINA, João. Prefácio in EÇA DE QUEIROZ, José Maria. A tragédia da Rua das Flores. Lisboa: Moraes Editores, 1980.

REIS, Carlos; MILHEIRO, Maria do Rosário. A Construção da narrativa queirosiana: o espólio de Eça de Queiroz. Lisboa: Imprensa Nacional-Casa da Moeda, 1989.

Recebido: 30 de setembro de 2013

Aprovado: 25 de novembro de 2013

Contato: cbarbieri@ig.com.br 